\title{
Nationalism and All That: Reassessing the Habsburg Monarchy and its Legacy
}

Galizien in Wien. Parteien, Wahlen, Fraktionen und Abgeordnete im Übergang zur

Massenpolitik, Harald Binder, Verlag der Österreichischen Akademie der

Wissenschaften, Vienna, 2005, 741 pp, 79.90 Euros, ISBN 3-7001-3326-X.

Vienna in the Age of Uncertainty. Science, Liberalism and Private Life, Deborah Coen, The University of Chicago Press, Chicago and London, 2007, 380 pp, 17 illustrations, \$US 45, ISBN 978-0-226-11172-8.

Oil Empire. Visions of Prosperity in Austrian Galicia, Alison Fleig Frank, Harvard University Press, Cambridge, Mass. and London, 2005, 343 pp, 12 illustrations, \$US 57.50, ISBN 0-674-01887-7 (hb), 0-674-02541-7 (pb).

Noble Nationalists. The Transformation of the Bohemian Aristocracy, Eagle Glassheim, Harvard University Press, Cambridge, Mass. and London, 2005, 299 pp, 6 illustrations, \$US 51.50, ISBN 0-674-01889-3.

Guardians of the Nation. Activitists on the Language Frontiers of Imperial Austria, Pieter M. Judson, Harvard University Press, Cambridge, Mass. and London, 2006, 313 pp, \$US 55.50, ISBN 0-674-2325-0.

Without Remorse. Czech National Socialism in Late-Habsburg Austria, T. Mills Kelly, East European Monographs, Boulder, 2006, 235 pp, \$US 40, ISBN 0-88033-586-6. 
Taming Balkan Nationalism. The Habsburg 'Civilizing Mission' in Bosnia, 1878-1914, Robin Okey, Oxford University Press, Oxford, 2007, 346 pp, £ 61, ISBN 978-0-19921391-7.

Das Februarpatent in der Praxis. Wahlpolitik, Wahlkämpfe und Wahlentscheidungen in den böhmischen Ländern der Habsburgermonarchie 1861-1871, Bernd Rottenbacher, Peter Lang, Frankfurt am Main, 2001, 709 pp, £ 75.80, ISBN 3-631-38260-X.

The Pomp and Politics of Patriotism. Imperial Celebrations in Habsburg Austria 18481916, Daniel L. Unowsky, Purdue University Press, West Lafayette, 2005, 270 pp, 58 illustrations, \$US 29.95, ISBN 1-55753-159-5.

Flag Wars and Stone Saints. How the Bohemian Lands Became Czech, Nancy M. Wingfield, Harvard University Press, Cambridge. Mass. and London, 2007, 353 pp, 35 illustrations, \$US 52.50, ISBN 0-674-02582-2.

Kidnapped Souls. National Indifference and the Battle for Children in the Bohemian Lands 1900-1948, Tara Zahra, Cornell University Press, Ithaca and London, 2008, 279 pp, \$US 39.95, ISBN 978-0-8014-4628-3. 
More than forty years ago Paul Schroeder stated that '[t]he status of Habsburg studies in the United States could easily be described in one word "flourishing". ${ }^{1}$ Surveying just a small portion in the wave of recent books on the Habsburg Monarchy and its successors many from American scholars - a more effusive word is required to describe the present state of the field. The current historiography is very different from when Schroeder wrote his review essay for the 1967 Austrian History Yearbook (AHY) conference. Then, there was a widely accepted view that the Monarchy's nationality conflicts had fatally weakened its strength and thus led, directly or indirectly, to its eventual dissolution. ${ }^{2}$ The principal elements of this paradigm were set by Oscar Jaszi in his classic The Dissolution of the Habsburg Monarchy published just eleven years after the end of the Monarchy. Jaszi concluded 'that the collapse of the Habsburg Empire was not anything surprising but rather the long continuance of this amalgamation of peoples without a common state idea, based on the mutual hatred and distrust of the various nations'. ${ }^{3}$ Jaszi attributed the collapse of the Monarchy to internal factors, isolating three as the most important: rising nationalism, a feudal class which prevented reform and 'the lack of any serious civic education'. ${ }^{4}$

In the last three decades the historiography has challenged all three of Jaszi's points. The study of nationalism has been transformed (mostly through constructivist and cultural approaches); the political system interpreted as relatively open, flexible and participatory; and the loyalty to the Emperor and the Monarchy reassessed. Pieter Judson has recently termed this change in Habsburg historiography a 'quiet revolution'. Beginning in economic history, much of this revision has roughly followed the leisurely progress of the massive series, Die Habsburgermonarchie 1848-1918. ${ }^{6}$ Originally 
conceived in the 1950s, the series has presented lengthy, detailed and authoritative articles on a wide variety of topics, including the neglected areas of bureaucracy, legal system, parliamentary life, constitutional government and, most recently, the public sphere and civil society. In addition, key works from American scholars such as John Boyer, Gary Cohen, Pieter Judson and others have also contributed to undermining Jaszi's negative assessment and have redirected research away from the overly schematic study of centripetal and centrifugal forces (significantly the 1967 AHY conference adopted Jaszi's framework). For example, in a recent article surveying the Monarchy's political development, Gary Cohen wrote that:

[t] he evolution of constitutional, representative government in the Austrian and Hungarian halves of the monarchy and the growth of a wide spectrum of political parties and interest groups demonstrates a broad process of modern political development during the half century before WWI. ${ }^{7}$

Cohen argues that nationalist loyalties co-existed with a continued allegiance to the Habsburg state. ${ }^{8}$ Instead of centrifugal forces tearing the Monarchy apart, Cohen suggests that 'most political groups in Austrian society [competed] for influence and control over parts of the state'. ${ }^{9}$ He therefore views nationalism as part of a vibrant, developing transformation of civil society and political life. ${ }^{10}$ Somewhat akin to Margaret Anderson's work on Imperial Germany, Cohen and other recent historians of the Habsburg Monarchy have argued that instead of a deficient political system, Austria like Germany - had developed a legitimate, functioning Rechtsstaat and a participatory, diverse and communal political culture. ${ }^{11}$

Of the books under review, the works by Rottenbacher, Binder, Mills Kelly, Unowsky, Wingfield, Glassheim and Okey all pursue variants of these ideas. The revisionist view does not necessarily deny the growing importance of nationalism (indeed 
many of the works under review retain the assumption of increasing nationalisation in public and private life) nor the numerous, profound challenges the Monarchy faced in the decades leading up to WWI, but merely notes that these challenges did not necessarily oppose or prove fatal to the continued existence of the Austro-Hungarian state. The monographs by Zahra and Judson introduce a new element, recasting the nationality question by emphasising 'national indifference' and its role in spurring nationalist activists. In place of the accepted view of rising, populist, mass, radical nationalism, Zahra and Judson highlight the difficulties faced by the nationalist activists as well as the continued bilingualism, indifference and pragmatism in much of the population. Finally, the books by Coen and Frank pursue their subjects with only occasional references to nationalist issues (Frank more than Coen). To some extent their work moves beyond the national question where it is a peripheral issue. This review essay groups the books into four sections: first, traditional political history; second, interpreting nationalist politics as a cultural system; third, 'national indifference' as an important element; and, fourth, nationalism as a mere background issue.

Taken together the books under review provide a variegated, rich and nuanced portrait of the Monarchy which stresses 'contingency, constructivism and complexity'. ${ }^{12}$ Over the last decade the sheer wealth of research on the Monarch has led to a remarkable pluralism where the nationality question is increasingly placed within its context, rather than being the overriding issue. ${ }^{13}$ 
Bernd Rottenbacher's book - a publication of his doctoral dissertation under Harm-Hinrich Brandt - evokes the world of political manoeuvring, electoral organizing, government influence and, most interestingly, the actual mechanics of the voting procedure. In traditional historiography, the Austrian political system - its constitution, parliament and electoral process - was judged harshly. ${ }^{14}$ Rottenbacher's carefully researched book provides much missing detail about the 1860 s, a decade crucial to Austria's political development yet surprisingly neglected in the literature. While not explicitly positioning his work against the existing historiography, Rottenbacher's explanation of Austria's gradual adoption of democratic institutions and the formation of political camps promotes a more balanced assessment of Austria’s political system.

Rottenbacher's study contrasts politics in Bohemia, Moravia and Silesia. Bohemia was the classic site of the Monarchy's nationality conflict. In the 1861 elections, however, this was not yet clear, as evidenced by a verfassungstreu, centralist Czech Franz Scebek and a federalist German Anton Porak. (219) ${ }^{15}$ Fairly quickly, though, the respective central committees took over and these anomalies disappeared as two distinct camps began to dominate: the centralists (or Verfassungstreu) and the federalists (the Czechs and conservatives). The Czech central committee, based around their press organ Narodni Listy, portrayed itself as the opposition party and set the standard for discipline in candidature and mobilization. The extensive network of Czech organizations, especially Sokol, emphasised the importance of Czech solidarity and rights. By tracing voting patterns, Rottenbacher emphasises the degree of homogeneity and continuity in Bohemia's electoral constituencies. For the period covered, from 1861 to 1871 , only 26 seats changed sides, mostly in the towns and mostly due to government influence. In fact, 
for a region known for national conflict, at this early stage of political development, there were very few swing seats to fight over. Thus the important battle was often within the nationalist camps. Rottenbacher also notes that apart from the crucial Great Landowners curia, Bohemia had a structural majority for the federalists' camp.

Rottenbacher emphasises that the Great Landowners' curia was the hinge of Bohemian elections and indeed the Reichsrat, at least until 1873, as Hoebelt has argued. ${ }^{16}$ The Great Landowner curia had a small, quantifiable number of voters and was always the last to vote, often a few days after the country, town and chambers of commerce curia so it provided the easiest and most effective means for a government to manipulate the result, as was famously done in March 1867 to create a Verfassungstreu majority favourable to the already agreed Ausgleich with Hungary. In mid-March Archduke Carl Ludwig personally met with leading nobles in Prague, then Brno/Brünn, to outline the Emperor's wishes. ${ }^{17}$ (117-8) Count Beust, recently installed as Foreign Minister, stated simply that 'the Emperor has spoken, the Emperor calls!'(116)

There were other levers the central government used to influence elections, as Rottenbacher makes clear. Bureaucrats could be candidates or be directed to vote en bloc, official newspapers and anonymous pamphlets circulated, sanctioned speeches given, police observation directed. Less subtle, more effective but also more controversial, were changes to electoral regulations and the tax threshold for voting. When drafting the 1861 system - in great haste and based on previously compiled information - Schmerling wanted a system where the result could be calculated and the government could exert subtle but decisive influence. (70-83) 
Electorally, Moravia was very different from Bohemia. The Great Landowners' curia was more amenable to the government and soon developed a government-friendly Middle Party. There were, however, a much greater number of possible swing seats in Moravia, especially in the town curia. Similar to Bohemia, the central committees quickly dominated political life. Silesia, on the other hand, had more stable election results where the Deutscher Verein dominated politics.

Rottenbacher's work raises a number of important correctives. While the traditional focus on the state and constitutional question is understandable, Rottenbacher's study shows that detailed investigations of elections, electioneering and electoral behaviour can be extremely fruitful. ${ }^{18} \mathrm{He}$ notes that politics was primarily organised according to the abstract state rights (which overlapped substantially with nationalities), not the familiar cleavages of town and country or religion. Polarisation came from above and the many homogeneous, mono-national constituencies partly explain the constant battles within political camps and the desire for a completely new constitutional system. Above all, Rottenbacher explains how the political system actually functioned and what concrete effects it had on subsequent development, rather than postulating possible alternative solutions to the Monarchy's constitutional and political situation.

Eagle Glassheim's book concentrates on the Bohemian nobility, who, despite some changes to the electoral procedure, 'in the $1880 \mathrm{~s}$... still held a towering position in Habsburg society and government.' (2) He charts their adjustments to modern life and the drastic changes in political and state rule from the fading grandeur of the Habsburg Empire in the 1880s to the radical communist reforms in Czechoslovakia upon their 
takeover in 1948. The nobles were by no means passive; updating their estates, forming political and lobbying groupings, all with the general aim of 'changing to stay the same'. (13) ${ }^{19}$ While the Bohemian nobles were prepared to keep pace with the new economic and political conditions, their social customs and practices became ever more exclusive in the modern age. Intermarriage between families, hunting on their extensive country estates, socializing at the Jockey Club in Vienna and the Ressource Club in Prague were all indicators of noble social standing.

Politically the main camps in Habsburg Bohemia remained centralists and federalists. Yet as the options narrowed and politics in Bohemia hardened along more nationalist lines, the Bohemian nobility adopted aspects of national belonging, either the Czech or German camps. This was exacerbated by the stance of the young Czechoslovak state formed out of the ruins of the Habsburg Monarchy. The Czechoslovak state based its legitimating ideology on a particular middle-class, democratic Czechoslovak view of history, the official line fought against possible monarchist and German separatist tendencies, especially within the Bohemian nobility. The Land Reform Bill of 1919 and the State Land Office provided a focal point for both noble activism and the 'nationalizing' nature of the Czechoslovak state. While the nobles sympathetic to Czechoslovakia relied on lobbying - including President Masaryk, his ministers and the officials at the Land Office - the German nobles used their international contacts and placed their faith in the League of Nations and its procedure for protecting minorities. Glassheim shows how the nobles, while retaining aspects of internationalization and social cohesion, were increasingly forced to choose national sides. 
The early 1930s were a respite for the embattled nobles as conservatism reasserted itself. In 1938 with Hitler's radical reorganization of the Central European map, there was the predictable split in attitudes. Many German nobles, who had increasingly coupled their cause to the plight of the Sudeten Germans, welcomed the formation of a greater Germany, whereas the Czech nobles, in two brave but futile declarations of 1938 and 1939, professed their loyalty to the Czechoslovak state. As Glassheim notes, these declarations were against their material interests and prevailing power relations, thus betraying a profound loyalty to the Czech nation. (150-2 and 199200).

The end for the Bohemian nobility came in two stages, first the expulsion of Sudeten Germans (including many German nobles) and appropriation of their property immediately after WWII and, second, a radical process of land reform spearheaded by the Communists which eventually led to the fragmentation of Czechoslovak country properties and the end to all large noble landholdings. Most nobles used their international connections to leave Czechoslovakia but a handful stayed and took various menial jobs in the Communist state.

Glassheim's work plots the transition from diversity to relative homogeneity in Central Europe over the course of the late-nineteenth century to mid-twentieth century. This chronology is similar to Jeremy King's book on Budweis/Čseké Budějovice and has been adopted by some historians of the Bohemian lands (for example, Wingfield and Zahra among the books under review) ${ }^{20}$ His concentration on a small group of important actors as they negotiated changing conditions enables detailed understanding and demonstrates the advantages of collective biographies. Along with recent work from Rita 
Krueger and Ralph Melville, it forms a trilogy of monographs on the Bohemian nobility with the only period missing, ironically, their period of greatest Imperial influence from the 1850 s to the 1880 s. $^{21}$

T. Mills Kelly's book focuses on the rise of the radical Czech National Social Party in the last decades of the Habsburg Monarchy. He places the Czech National Socials firmly in the political, social and economic context of the Monarchy's move to mass democracy and modern industrial conditions. Mills Kelly identifies a number of reasons for the Czech National Socials' relative success. Most important was the party's voting support mostly found in the geographic areas which had modernised early, had attained a high standard of living, but had subsequently lost their position relative to other areas. These 'objective conditions' of rapid development and commensurate prospects, followed be a relative fall in fortunes created the seedbed for a Czech National Social voter. Another factor, according to Mills Kelly, was the asymmetric political structure in early twentieth century Bohemian politics. While equal, universal suffrage was introduced into the Reichsrat in 1907, the Bohemian Diet and local council elections continued to be held under the curia system. In effect, this allowed the radical, populist politics a forum as a minority party in the Reichsrat's Czech club but denied them any chance of participation in regional or local government. Thus the politics of the street and of opposition - mass demonstrations, clashes with the police and with German speakers, mock trials - could be used by the National Socials to present themselves as the legitimate leaders of the Czech nation, unsullied by involvement with the Viennese government (like the Young Czechs) or a commitment to internationalism (like the Social Democrats). Ideologically, as well, there was space for the National Socials' message of 
Czech nationalism, anti-Semitism, social reform, anti-militarism (hence mildly antiHabsburg) and egalitarianism (hence pro-women voting). Indeed, the National Socials pushed for a complete transformation of Czech life and the full democratization of public life.

Mills Kelly, like Lothar Höbelt on the German radical nationalists, stresses the opportunistic and often pragmatic nature of late Imperial mass politics, where despite heated rhetoric and violent street demonstrations, the political leaders remained open to electoral and parliamentary alliances. ${ }^{22}$ The best example is the electoral arrangement between the National Socials and their bitter rivals, the Young Czechs, in the 1911 Reichsrat elections. Echoing Rottenbacher's observation, Mills Kelly argues that the mostly mono-national constituencies in Bohemia contributed to radical politics 'without remorse'. (132) The 1907 electoral redrawing of the boundaries emphasised this electoral separation, thus turning Czech parties against one another, while their anti-German rhetoric showed no signs of abating. Mills Kelly is illuminating about the rise of Czech radical nationalism and its place in the Monarchy's political process, but he does not engage fully with the larger issue of radicalisation throughout the Monarchy and the possibility of the state's continued existence. In his conclusion he notes that the zero-sum game of Czech politics, where compromise was perceived as failure and radical politicians often outflanked more moderate voices, was a bad style of politics and a grave legacy to leave the new Czechoslovakian state. More on these continuities with later politics would have been illuminating.

Galician politics was dominated for many decades by the conservative Polish nobles and, in many respects, had the characteristics of the periphery - slower social, 
economic and cultural development. Its multi-ethnic and multi-confessional character, Binder argues, not only brought conflict but adaptation, accommodation and a certain notion of Galician identity.

The orientation of nationalities as a construct was at least for the later years absolutely fundamental, but the national differentiation did not mean that there wasn't mixing, plurality and ambiguity in the realm of cultural identity. (24)

Binder divides his work into a strict schematic structure with four main sections - Parties, Elections, Fractions and Representatives - and many sub-sections. While aiding clarity, the separation of themes and subjects sometimes obscures the inter-related web of connections and relationships which made up the Galician political system. For example, little is made of the connection between the Polish Central Committee, set up for elections, which directly fed into the powerful, parliamentary Polish Club. (190-201 and 321-36) He barely touches upon the overlapping functions of important politicians who were often members of the electoral committee, party executive and parliamentary fraction. Similarly in his analyses of the 1897, 1900-01, 1907 and 1911 Reichsrat elections - while there are good individual discussion of the campaigns, changing issues and electoral results - there is little sense of how Galician democracy and politics functioned on the ground; the formation of electoral committees, selection of candidates, organisation of campaign rallies, the interaction between different candidates, the procedure at polling day and the varied responses to the results. This is partly due to Binder's thematic, panoramic approach but also reflects his major primary sources - local and Imperial newspapers alongside parliamentary and administrative records. Binder does not use party archives or politicians' personal papers - indeed there is little on individuals, even such a prominent figure as Stanisław Stojałowski. Instead, Binder 
concentrates on structural relationships (conservatives/democrats,

Russophiles/Ukrainophiles, German Jews/Polish Jews) and long-term processes (mass politicisation, the formation of democratic structures, elite formation).

His work, nevertheless, provides an excellent, albeit lengthy, introduction to Galician politics from the 1890s to the end of the monarchy. Polish, Ruthenian and Jewish politics are investigated in depth and with considerable insight. There are extremely thorough and detailed discussions of individual Reichsrat elections from 1897 to 1911 with telling examples from individual constituencies. His discussion of 'Galician Elections', where accusations of official electoral corruption were widespread, is particularly revealing and is similar to Rottenbacher's observations on 1860s Bohemian politics as well as long-standing views on Hungarian elections. ${ }^{23}$ Similarly the fractions in parliament are covered for each parliamentary session from 1897 to 1918 with the Polish Club's fortunes forming the central narrative thread. In general the Ruthenians grew in parliamentary strength as their number of representatives increased and they were prepared to use obstructionist tactics. More on the relative strength and activity in the Galician Landtag would have broadened the picture on the Polish/Ruthene conflict in these years. The weakest section is on the representatives where Binder's sociological analysis of Polish, Ruthenian and Jewish representatives based on age, confession, jobs, education and various other categories uncovers nothing particularly revelatory. Ultimately Binder's painstaking work has provided a comprehensive study which, while not rethinking the field, is a solid base for investigating Galician politics.

Robin Okey's book on the Habsburg Monarchy's occupation of BosniaHerzegovina is based on contrasting and competing visions of development. On one side 
was the Habsburg 'civilising mission' which gave moral legitimacy to the Monarchy's policy of preventing the development of a large South Slav state as a dangerous neighbour; on the other side were the three nations in Bosnia-Herzegovina - the Muslims, Orthodox Serbs and Catholic Croats - who believed in their own higher destinies. Yet, as Okey continually stresses, the story of occupation was not simple; it had many subtle nuances as well as regional commonalities. Okey places the Habsburg civilising mission squarely within Edward Said's concept of Orientalism; namely Western arrogance about bringing rational, universal values to primitive, undeveloped peoples.

In the first chapter, Okey provides an excellent background to the difficulties faced by Austria-Hungary when it occupied Bosnia-Herzegovina in 1878. In particular the three contrasting communities of Bosnian Muslims, Orthodox Serbs and Christian Croats each had their particularities, feuds and hierarchies. Quite early in the occupation the government followed the familiar Habsburg integration policy of combining a cultural and progressive mission coupled with reliance on local religious hierarchies to maintain control. Thus the immediate primary goals were the establishment of a strong, prestigious administration and gaining control over the three religious hierarchies. Both goals proved difficult to achieve. For example, the administration's attempt to found inter-confessional schools struck the minefield of an entrenched, confessionally structured society while the administration's religious appointees proved stubbornly independent. Dissatisfaction erupted in 1882 when, because of agrarian and tax grievances, first the Serbs, then the Muslims staged a substantial insurrection in Herzegovina. This ushered in the imposing figure of Benjamin Kállay who would run the provinces from 1882 to his death in 1903. 
Kállay's regime was built on a paradox; the belief in the integrating effects of religious tolerance within the framework of a progressive, modern society, counterposed with a constant fear of insurrection and dissent, especially from the Orthodox Serb population. His approach was thus an awkward combination of strong government (stick) and civilising mission (carrot). The heart of the book lies in the three separate chapters on Kállay's policies and attitude towards the Serbs, Muslims and Croats. Interestingly, Kállay probably had the most success with the Muslims where a significant section of the intelligentsia welcomed European influences and became at least partly Austrophile. In dealing with the Serbs, Kállay's academic work and experience working in the Austrian embassy in Bucharest proved to be of little help. His attempt to control the religious community met with resistance, while Serbian nationalism only grew in response to his strong government. The Catholic Croats were torn by a feud between Archbishop Josip Stadler and the traditional religious leaders, the Franciscan order. In addition, to maintain the appearance of confessional equality Kállay occasionally intervened against the Catholic Church. These difficulties came to a head during the late 1890s as both the Serbs and Muslims pushed for autonomy and the government's increased use of the secret service laid bare the failure of Kállay's policies.

Okey’s work positively reassesses the policies of Kállay's successor, István Burian, describing them as 'distinctive and considered', if also somewhat conservative, inflexible and based on the false assumption that the elites controlled their respective constituencies. (191) Autonomy was granted to the Serbs and in 1910 a constitution with a representative, regional Diet came into effect. Inevitably, once the provinces were annexed in 1908 and brought within the Monarchy's complicated and delicately balanced 
dual constitutional system, many parties wanted influence in its administration and politics.

The final two chapters are written in the shadow of Gavrilo Princip's fateful assassination of Archduke Franz Ferdinand. Clearly the 'civilising mission' had not worked. Instead of promoting enlightened citizenship within and loyalty to the Habsburg state, secondary schools had become focal points for discontent, dissent and activism. Student groups such as Young Bosnia (Princip belonged to a breakaway group) sprang up advocating violence and freedom from Austrian oppression. Okey brings the reader to the precipice but does not recount the familiar story of Franz Ferdinand's assassination. His assessment of the 'civilising mission' is succinct: “[w]ith the training of minds had not come a winning of hearts". (247) While there were successes in infrastructure, urban growth and the economy, Western education was often seen as undermining native development. For many within Bosnia-Herzegovina, 'progress' would preferably be through nationalist institutions, not a Habsburg cultural mission.

Okey's work adds much to the historiography of the Habsburg Monarchy. There has been little in English on the Bosnia-Herzegovina administration and none have covered it in such breadth, depth and detail. Indeed, some small sections could easily have been expanded into chapters of their own. Okey's ability to compress information is admirable if occasionally wearisome in its constant wealth of detail. His career has been the inverse to the norm - from very broad canvas to large synthesis to focussed monograph. ${ }^{24}$ This volume, a reworking of his doctoral dissertation submitted thirty years ago, caps his distinguished career in Habsburg historiography. 
$* * *$

In her ambitious, wide-ranging book, Nancy Wingfield uses a strong 'constructivist' approach to analyse the increasing symbolic possession of public space, asserting that ' ....[all] national claims are the product of strategies, stories, narratives, monuments, holidays and other cultural artefacts.'(14) Her overriding question is how the politicization of local cultural and social life, through statues, memorials, holidays and celebrations, led to nationality becoming the key to all aspects of everyday life.

The first chapter, which charts the changing Bohemian view of Joseph II, provides a good example of Wingfield's argument. In the few decades after Joseph's reign, the official memory of a well-meaning, overworked ruler co-existed with the popular memory of the Volkskaiser who had passed progressive decrees (including the lifting of serfdom). The German liberals of the mid-nineteenth century, however, claimed a different aspect of Joseph's protean legacy - his desire for a centralised, unified and rational state. When the liberals' unexpected and debilitating loss in the 1879 Reichsrat elections coincided with the 100 year anniversary of Joseph's accession to the throne, the Bohemian German liberals used the erection of Joseph II statues to symbolise the continuing strength of the German community and its importance to the Austrian state. While peasants were occasionally involved in these ceremonies, the general trend was a move from a historic figure with multiple meanings to the celebration of a German saint, the unofficial patron of Bohemian Germans.

The next chapter, on the Bohemian German demonstrations surrounding the Badeni Decrees, emphasises the increasing use by both Czechs and Germans of the 
language of exclusion. Wingfield argues that a pattern of violent demonstrations was developing and that fear for the loss of status drove the Bohemian Germans towards becoming one community, a Volksgemeinschaft. The remaining chapters trace how these intertwined processes of increasingly dominant nationalism and more exclusionary, proprietorial national rhetoric played out in the Bohemian lands. Wingfield concentrates on the flashpoints - Brno 1905 over the Second Czech University, the contested 1908 Francis Joseph Jubilee, the foundation of the Czechoslovak nation-state in the immediate aftermath of WWI, national holidays in inter-war Czechoslovakia and the 1930 riots over German sound films in Prague. Her discussion of Czechoslovakia is particularly good. ${ }^{25}$ Like Glassheim, she classifies Czechoslovakia as a 'nationalising state' - constantly legitimating its existence by using the past and erasing inconvenient symbols (mostly German, Habsburg and sometimes Catholic) to promote one national vision. Wingfield is understandably critical of this exclusionary vision which found no room for Germans, Catholics, Hungarians, Poles and Ruthenians (along with many Bohemian nobles as Glassheim has highlighted). In a later chapter Wingfield describes the Sudeten German attempt at constructing their own exclusive community in the 1930s under the aegis of the increasingly Nazi Sudeten German Party.

Wingfield provides a different slant to a familiar story; of the breakdown between Czechs and Germans, of exclusionary, racial, proprietorial rhetoric where there was once co-existence and acceptance. The coverage, while admirably broad encompassing film, holidays, statues and flags, is so varied that the book occasionally loses focus, not helped by some narrative jarring (for example, the Czech legionnaires, who fought on the side of the Russians in WWI, are discussed in relation to the immediate post-WWI riots in 
Chapter Five but are only really explained in the following Chapter Six). In general, Wingfield concentrates on how the differing authorities and organisations mobilised people, without investigating who the people in the crowd were, what motivated them and how they perceived and understood the various demonstrations, celebrations, holidays and national events. For example, the cinema riots involved a minority of Czech Fascist agitators, while many 'loyal Czechs' simply wanted to enjoy some sentimental German-language film in the latest technology. This ambivalence could have been more deeply discussed. Nevertheless, her book is a welcome addition to the new literature on Czech-German relations and considerable widens the scope for further research.

Daniel Unowsky's book focuses on imperial celebrations and the image of the Emperor Francis Joseph. By analysing the Imperial visits to Galicia and various anniversary celebrations in Vienna, Unowsky argues that there were concerted efforts at projecting the Emperor's image and that these efforts changed over time as different groupings became involved and the general political situation developed. Thus Unowsky compares the 1851 Imperial visit to Galicia - when the army, police and court combined to convey the Emperor's grandeur, magnificence and control over state power - with Francis Joseph's three week visit in 1880, which was stage-managed by Polish conservatives to portray Polish achievements under a conservative-dominated, administratively autonomous Galicia. Significantly, whereas the military and the police had been responsible for security in 1851, a Polish citizen's guard kept order during the 1880 visit. There were, however, challenges to this dominant 1880 Polish conservative narrative, principally from the Ruthenians but also to some extent from the region's Jews. Francis Joseph duly visited their respective religious buildings and met Ruthenian and 
Jewish representatives during his visit. Unowsky argues that this contestation for the Emperor's patronage intensified for a short visit in 1894 reflecting the heated political situation, but regrettably he does not analyse this 1894 trip in any depth. Indeed there are few voices from the crowds themselves and how their reception of the Emperor may have changed with differing circumstances or, indeed, stayed much the same despite the political manoeuvring behind the scenes.

The section on the revival of religious rituals and Imperial ceremony in the neoabsolutist era is particularly compelling. This laid the template for the Imperial Court's representation of Francis Joseph as a pious yet superior ruler. Over the years, especially after the violent deaths of Crown Prince Rudolph and Empress Elisabeth, this image was adjusted to incorporate these personal tragedies. Emphasis was now placed on Francis Joseph's sacrifice, perseverance and sense of duty while his own human characteristics were further obscured behind the official line. It was this basic image which was disseminated through schools, voluntary associations and local councils. Nevertheless, as Unowsky demonstrates, there continued to be politically motivated contestation over Imperial patriotism. For the 1898 celebrations, nearly all of which were cancelled due to the Empress Elisabeth's assassination on 10 September 1898 , the recently installed Christian Social council in Vienna attempted to remake the Emperor's image and define patriotism along Christian Social principles (namely mild anti-Semitism, opposition to Pan-Germanism and Socialism).

The overall argument of increasing contestation for Francis Joseph's image is convincing (and contrasts with Wingfield's nationalising of symbols) but a more detailed discussion of the 1908 celebrations would have strengthened Unowsky's book. It is 
strange that the centrepiece of the book - three chapters on the 1898 anniversary celebrations - is about events which were planned but mostly did not take place. His book is a reminder of the continued loyalty to the dynasty and the key position of the Emperor within the monarchy's complex, fluctuating system.

Wingfield's and Unowsky's books form two sides of the same coin. Wingfield's cultural analysis of nationalist riots, demonstrations and holidays obviously differs from Unowsky's similar approach for Imperial celebrations, visits and representations. Both aspects co-existed in the Monarchy and in all probability even shared participants - in many towns, mayors and local notables would, for example, attend the unveiling of a Kaiser Joseph II statue as well as an Imperial visit. Unowsky neatly states that in the Monarchy 'dynastic patriotism and national belonging were presented as mutually reinforcing rather than mutually exclusive'. (3)

$$
* * *
$$

Tara Zahra's innovative book inverts the traditional arguments of mass, radical nationalism from below in the final decades of the Monarchy and argues that the nationalists were spurred to increasing radicalism by the masses' indifference and ambivalence towards nationality. Thus '... indifference to nationalism [should be] a central category of analysis, a driving force behind historical change in East Central Europe'. (4) Indifference to politics was not new; Rottenbacher noted that for the 1861 elections the most common complaint in reports from the Landgemeinde was the disinterest of electors. ${ }^{26}$ However, especially for the turbulent early to mid-twentieth 
century, national indifference has rarely, if ever, been seriously discussed. Zahra's book, along with her former teacher Pieter Judson's, should prompt a reassessment of the nationalisation process in Central and Eastern Europe..$^{27}$

Zahra highlights the interaction between pragmatic, flexible, nationally ambiguous, ambitious parents and the respective Czech and German nationalist visions as a site for the shaping of democratic ideals, minority rights, the modern welfare state and ideas of ethnic purity. By concentrating on the children who were bilingual - products of mixed marriages and in constant contact with both Czech and German speakers - Zahra demonstrates the extreme fluidity of national loyalties despite the continual attempts by both national sides and the different state regimes to 'objectively' classify the population according to nationality. Zahra argues that despite the radical changes in political regimes, strong continuities existed in nationalist thinking and practice as well as fundamental similarities between the two nationalist movements. Instead of the traditional representations of Masaryk's Czechoslovakia as a beacon of liberal democracy and the Third Reich a brutal, racial oppressor, Zahra argues that the roots of many nationalist policies for children in both regimes can be traced to nationalist theory, rhetoric and organisation from the later years of the Monarchy.

The first chapter outlines the change from liberal assumptions on schooling in the mid nineteenth century (namely, nationalism and religion were a matter of the private sphere) to the early twentieth century, when after decades of nationalist politics, the idea prevailed amongst national activists that children belonged primarily to the nation, not to any private sphere or parental realm. Bilingualism, parental pragmatism and national indifference were condemned by nationalists as exhibiting a lack of character and moral 
degeneracy. Both nationalist movements raised funds, built schools and promised gifts in a bid to maximise student numbers in their respective, segregated school systems. The German nationalists, with echoes of their liberal heritage and centuries of state and cultural patronage, welcomed as many children as possible into their school with the promise of upward social mobility and the possibility of assimilation. The Czech activists, on the other hand, wished to retain as many children in the Czech-language education system and insisted that there would be no disadvantage with future prospects. Thus segregated educational systems co-existed and a vicious culture of national denunciation within national communities developed. The Moravian Compromise and the Lex Perek entrenched this national segregation and empowered administrative authorities to determine a child's nationality based on 'objective characteristics' ${ }^{28}$

This combination of state sanctioned national segregation and growing social welfare infrastructure along nationalist organisational lines continued and strengthened during the difficult war years from 1914 to 1918. In the last years of the Monarchy, nationalist activists functioned as privileged mediators between the state and their respective national communities. These trends continued and deepened in the new Czechoslovakia with one crucial difference; the state was now firmly on the side of the Czech nationalists - indeed, Czech nationalism provided a basis for the country's legitimacy - and the 'objective' ascription of nationality became heavily biased in favour of the Czech side. Collective rights underpinned Czechoslovakian institutions and membership was determined by Czech authorities. There were two strands to the Sudeten German response - paralleling many similar positions in the nineteenth century - the negativist Heimat movement, which denied legitimacy to the Czechoslovakian nation- 
state, and the positivist work of the German Provisional Commission for Child Welfare (DLS), which worked with the Czechoslovak authorities. Gradually, in the 1930s, the Sudeten German Party, which was always close to the Heimat movement, infiltrated and took over the DLS.

Nazi practice in the Sudetenland and the Protectorate of Bohemia and Moravia involved a radical racial reordering of the region but, argues Zahra, in fact followed many local traditions of nationalist activity. Thus national classification under the Nazis resembled the procedure in the Habsburg Monarchy and the Czechoslovak state, though there was more space to be politically loyal to Nazi Germany while remaining Czech. National indifference, side-switching and pragmatic choices about allegiances continued. In particular, Sudeten Germans slowly became disappointed at Nazi education policies which prioritised the war effort over the threat from the Czechs at home. Committed Czechs, on the other hand, called for a defence of their ethnic purity and, in a reverse of the previous suspicion of pragmatic parents, entrusted Czech mothers with the correct Czech upbringing of their children. Zahra highlights the rather paradoxical Nazi Kuratorium for Youth Education which organised summer camps and mass demonstrations for Czech youths, all in the spirit of Czech nationalism, in order to engender Czech loyalty to the Third Reich. There was some measure of success with this policy, though this Reich-loyal Czech nationalism has been largely been neglected by researchers.

In a short epilogue Zahra looks at the immediate post-WWII situation and argues sweepingly that ' $[\mathrm{e}]$ thnic cleansing was not just a radical solution to national conflict in Europe: it was a final solution to the persistent problem of national hermaphroditism and 
ambivalence'. (264) Only national purification could solve the problem of diversity, bilingualism and national flexibility. In Zahra's account, the national activists, especially when they had the backing of a powerful state machine (whether Czechoslovakia or the Third Reich), took centre stage as they battled the other side and their own nationally indifferent populations.

Her book is a sophisticated, empirically rich study on nationalist claims for children and forces a substantial reassessment of the nationalist struggle. National indifference (indeed, political indifference) should be a consideration in any discussion of the region's history. Yet there are still unresolved issues. The nationalists' own records and publications can certainly be used counter-intuitively to demonstrate national indifference. But how much was this an internal strategy or rhetoric appealing to fellow nationalists to renew their efforts in the face of unresponsive parents and the general population? Though it would be difficult to estimate, how widespread was national indifference? Indeed in comparison to other political movements (Socialism, Agrarianism), how did radical nationalism fare in the scramble for political mobilisation? Nationalist aims were so all-encompassing - every person to be absolutely committed to one nation - that activists were bound to fall short and be disappointed. While segregated educational systems and social welfare networks definitely entrenched national communities, the initial segregation clearly had nationalist motivations. In other words, the nationalist dynamic as described by Zahra - nationalist activism met with relative indifference leading to national radicalism - is predicated on the existence of strong nationalist activism by at least some part of the population. These nationalist movements recruited large numbers of followers, as Mills Kelly and Wingfield make clear, so there 
must have been a certain latent nationalist sentiment in at least a significant part of the population. At the very least there was a large spectrum of national belief and indifference. Overall Zahra's book is an impressive achievement which not only challenges existing paradigms of nationalist politics but pioneers the study of childhood in Central European historiography.

In Pieter Judson's book rural nationalist violence in Bohemia and Southern Styria (now part of Slovenia) during the final decades of the Habsburg Monarchy is subjected to similar intense investigation and questioning. Judson poses thorny questions which, like Zahra, challenge the existing paradigm of the politicised masses pushing for change by extra-parliamentary means. Who actually participated in the violence? Did the participants have nationalist motives? What larger meanings did local communities attach to the violence? Combining analytic approaches from literary studies, cultural anthropology and critical theory (in particular Foucault) with meticulous historical scholarship, Judson draws the veil from nationalist mythmaking and attempts to give voice to the silent object of the nationalisation process - the rural population. Like Zahra, he asserts that national indifference, flexibility and acceptance remained strong factors, despite the increasing nationalist rhetoric and radical tactics of the politicians and activists. In line with current research (which he partly inspired) Judson writes that language frontiers and nationality were not eternal and natural but had been created by the specific combination of Imperial censuses, an embattled Austro-German elite and increasing nationalist rhetoric.

When bourgeois nationalism confronted the bilingualism, social fluidity, national indifference and pragmatism of rural, mixed-language regions, the national activists on 
the language frontiers privately complained of unreliability yet publicly praised the heroic behaviour of their brethren on the frontline. Potent symbols such as schoolhouses, buildings and statues laid claim to the landscape as 'national property' (Nationalbesitzstand). Judson is particularly good on the common, coherent narrative structure which had evolved to explain schoolhouse attacks. The main elements were an unprovoked attack, threats to children and the calm, level-headed response of the teacher. Yet in reality the 'attack' may only have been, in essence, a drinking prank, such as in Lichtenwald/Sevnica in Southern Styria.(58) Nevertheless, for the national activists and their press, every misunderstanding, insult or violent incident took on national significance, even when the incidents may not necessarily be nationalist in motive. Nationalist rhetoric postulated fixed language frontiers and claimed territory as 'national property' but, Judson asks, did the rural population really become nationalist?

The agents of national activism were the newcomers to rural Austria - teachers, civil servants, doctors, railway workers, among others - who often brought a double vision of modernity and national community. Thus nationalisation, for the activists, had a moral basis and terms such as education, hygiene and commerce were extolled as national virtues. The modernisation process, Judson argues, should be decoupled from nationalism. (7-8) Throughout the book Judson uncovers the rhetorical structures which underpinned the nationalist Weltanschaung. This is particularly the case with a focused chapter on nationalist violence over three days in 1908 in the predominantly Germanspeaking, Bohemian villages of Bergreichenstein/ Kašperské Hory and Schüttenhofen/ Sušice. He contrasts three separate accounts - the Czech, German and government versions. The Czechs blamed the violence on provocative German policing, a mob of 
German students (as well as some notables) and the collusion of the German-majority municipal council - a familiar trope of overbearing German authorities and arrogant German bourgeoisie. The Germans accused the Czechs of inciting the clash, Czech civil servants for organising the Czech crowds and Czech troops for using excessive force leading to a death at the hand of the gendarmes. Here the calm, moderate German students are contrasted with the provocative, hot-headed Czech gendarmes. Finally, the government reports tried to minimise the nationalist significance and to concentrate on the facts. Judson emphasises the creation of these differing yet coherent dramatic narratives. He also places much of the blame on bourgeois participants, especially the students and activists, who pushed for confrontational situations that could conceivably lead to violent incidents. In fact, as a district administrator's report made clear, many locals were more concerned that their market day had been disrupted.

Judson also looks at nationalist tourism. Südmark, which was reasonably successful with an expensive colonisation plan at St. Egydi/Sv Ilj, trumpeted their flagship programme and encouraged visitors to this 'model of national community'. (128) Of course, St. Egydi also laid claims to territory and formed part of a projected linguistic bridge between the majority German-speaking areas of Styria and the 'language islands' of Marburg/ Maribor, Cilli/ Celje and Pettau/ Ptuj. In Bohemia, Höritz/ Hořice na Šumavč was the subject of Böhmerwaldbund publicity advertising its annual passion play. Yet there was considerable ambivalence in such tourism because, while overt national activism was generally good for the tourist trade, the play's effect was emotional, even religious, not necessarily national. 
In his final chapter on World War One - which is more speculative than the others - Judson identifies a turning point when, because of different conditions and the nationalised welfare systems, the nation truly entered into daily life. The successor states, which based their legitimacy on claims to be a single nation, took the final step in territorializing the landscape by claiming national borders as political borders. The effects and policies were, of course, localised but the steps towards the radical population practices of the mid-twentieth century had taken place. In their stimulating works, Zahra and Judson raise important questions about the exact operation of nationalism within the general population and everyday life.

$* * *$

Alison Frank's book charts the competing visions of Galicia through the little known story of the rise and fall of Galicia's oil industry. It reached the dizzying heights of the third largest oil producing region in the world, accounting for $5 \%$ of the world's production in 1909 , only to decline inexorably afterwards. It is a compelling narrative told from a number of perspectives: Austrian, Galician and local; heroic oil barons and poor workers; big foreign capital and small amateur investors; the Austrian military and suffering oil workers in World War I; the Poles, Ukrainians, British and French in the unstable post-1918 world. Above all, Frank is careful to convey the complexity and diversity of the Galician oil industry.

Frank begins her work with a characterisation of Galicia containing familiar elements. While a constitution and regional diet were in place from 1861, economic backwardness and the conservative Polish landowners' iron grip on power translated into 
a poor province wedded to agriculture. Like Binder, Frank mentions the social injustice and electoral abuse which was rife in Galician politics. However, Frank's account perhaps underemphasises the real and growing opportunities for social mobility and civic participation that existed amidst the poverty and entrenched hierarchies of Galician life. ${ }^{29}$ In the early years of the Galician oil industry, roughly from 1862 to 1884 , the central government in Vienna was not particularly interested in this peripheral good only used for lighting, and let the Galician Diet determine regulations. The principle of private rights, rather than crown control, prevailed and issues of land ownership, private property and local control dominated the industry. For a number of reasons, mostly related to private ownership of rights, the industry did not flourish and in 1884 an Imperial Petroleum Law was introduced combining state supervision and private control.

The stage was set for the boom years of Galicia's oil industry. Large oilfields were found and fortunes made. Legendary oilmen made their names in the 1880 s, men such as Stanislaw Szczepanowski, born in Prussian Poland who worked for years in London, and William McGarvey, originally from Canada and the introducer of modern drilling technology to Galicia. Szczepanowski's tale is a cautionary one. A committed Polish patriot - Szczepanowski dreamt of being a 'Polish Cavour' - he regarded 'oil [as] an opportunity to rescue Poland'. (89) He believed it could lead to the economic and spiritual rebirth of the Polish nation. A member of the Imperial Parliament and the Galician Diet, Szczepanowski - never the most orderly of businessmen - neglected his business while the Galician Savings Bank, run by another Polish patriot, continued to fund Szczepanowski based on his reputation. In 1899 there was a run on the bank and Szczepanowski's ruinous finances were laid bare to the public. Frank shows how the 
Szczepanowski scandal not only involved purely financial issues, but also questions of national regeneration, Galicia's future and Polish patriotism.

Frank's chapter on the oil workers is bracing and convincing. 'One thing', she writes, 'is clear: oil workers did not act as Galicia's revolutionary class.' (109) Most workers, Frank argues, were itinerant, often disregarded safety regulations and held national and confessional identities above any putative class consciousness. The occasional riot often had anti-Semitic undertones rather than any workers' movement for fundamental reform. Even the extensive strikes of 1904 had little socialist influence. By the turn-of-the-century Galicia's oil industry had transformed and become big business. Discovery of new massive oilfields in the 1890s and 1900s (including the famous 'Oil City'), more investment (including big foreign capital), developing technology plus a potent combination of too many companies and too little co-ordinated action led to an epidemic of overproduction and a catastrophic fall in prices. Despite state-sponsored recovery of prices, the oil industry would, unbeknownst to most experts, enter into terminal decline.

World War I only emphasised the gradual slide in production, to the extent that in 1917 the Central Powers, including the Austro-Hungarian navy which had committed itself to oil-powered ships on the back of Galician oil, reached crisis point. The overproduction before the war had also prompted increased private consumption which, coupled with military requirements during the war and dwindling reserves, exacerbated the recurring difficulties in the Galician oil industry (transport cost, lack of vertical integration, expensive refinery costs). When - after WWI, fruitless negotiations in Paris 
and civil war - Eastern Galicia officially became part of Poland in March 1923 its oil industry was in terminal decline.

Frank's book reads like a moral fable of economic backwardness, lack of legal structures and a heady recklessness which meant the oil industry never regenerated the region (or greater Poland) and has not left many lasting traces. Her careful study suggests that while nationalism was important, it was merely one factor among many.

Nationalism barely makes an appearance in Deborah Coen's ambitious, multilayered, fascinating work covering a century of Viennese intellectual history through the lens of the remarkable Exner family. Addressing an array of academic disciplines including philosophy, education, Roman law, colour theory, physics, neurophysiology, biology and meteorology, Coen identifies an underlying preoccupation to these diverse investigations - probabilistic reasoning. Coen argues that in an increasing secular world the Exners plotted a course between religious dogmatism and radical relativism by confronting and managing uncertainty in a multitude of contexts and scientific fields. (26) According to the Exner family's mantra, a clear-sighted and rigorous education based on empirical science would equip an individual with the ethical character to critically and independently engage with an uncertain world and to exercise freedom responsibly. (22953) Family life, especially the culture of the summer retreat (for the Exners, their beloved Brunnwinkl in the Salzkammergut), was an integral component of a truly liberal upbringing. The final goal was an individual with Vielseitigkeit and a cohesive society of uniquely gifted people which, Coen believes, may have been highly achievable at the utopian retreat of Brunnwinkl but ultimately impossible through a rigid classroom on a mass Imperial scale. (337) 
While the Exner family members have not been neglected in their respective fields, Coen is the first to deal with the family as a whole. Similar to Karl Heinz Rossbacher's recent book, which covered five prominent Jewish (from roughly the same milieu as the Exners and with many social and familial connections), this approach often facilitates unexpected and fruitful juxtapositions, especially in the relationship between science and culture, such as Coen's discussion of colour theory and the Secession. ${ }^{30}$ Occasionally these ingenious connections seem forced. For example, in chapter five, Coen uses the themes of inheritance to weld together discussions on the law, biology, constructed family narratives, the 'universality' of education and women's rights. Were these separate, relatively discrete fields conceived (deliberately or subconsciously) as part of a larger issue? This comes to the heart of the book. By emphasising the overarching theme of probability reasoning, which Coen asserts dominated from the 1840s to 1940s, she perhaps underemphasises the specificity of the various, separate investigations.

Nevertheless, Coen's book is a considerable achievement and contributes to the ongoing assessment of Austrian liberalism. In particular, it focuses attention on the role the natural sciences played in the Bildung ideal of the liberal reformers. It also reinforces the sheer scale of the liberal project. In 1846 Franz Exner, the founder of the academic dynasty, half jokingly rhapsodised about the liberal future:

Fresh air began to blow through the land ... On its currents came free speech ... trade and industry flourish inside and out and multiplied Austria's honour and power. Each of us had a wife and sons. (55)

The final sentence points to another important corrective highlighted by Coen; the importance of family life to creating a society of ethical, liberal, free individuals. Her discussion of the summer retreat is particularly apposite and reveals an aspect not often 
dealt with in historical works. Indeed, throughout the book there is a tangible feeling for the texture of everyday life within Vienna's privileged Bildungsbürgertum.

****

Near the end of Act I in Hugo von Hofmannsthal's and Richard Strauss's very Viennese opera, Der Rosenkavalier, the Marschallin muses: 'It is in the 'how', there lies the whole difference'. Nearly all the books accept the growth and importance of nationalism but they differ in explaining how it developed and how its dynamics worked. Rottenbacher, Mills Kelly, Glassheim and Binder focus on politics and how - through organisations, the press, parties, campaigns, fractions and elections - nationalism began to dominate the political scene. Okey's approach is more traditional; outlining the state's grand project of integration, the difficulties and resistance it faced, then its ultimate failure. Wingfield and Unowsky explain how national contestation for public symbols, space and ceremonies evolved. Zahra and Judson both point to national indifference as a spur to national activists. Judson's work is the most subversive, hinting at widespread indifference and ambiguity, yet in his final chapter he concedes that in WWI the state effectively become nationalised. Finally, Frank and Coen pursue their respective investigations with the national question as a background issue.

Clearly nationalism was an important issue in the later years of the Monarchy and for the region throughout the twentieth century. It will no doubt continue to be the subject of research and debate. However, with the EU, accepted state borders and less political contestation, perhaps there is an opportunity to step back and reassess the outlines of the 
Monarchy's history and legacy - to create a new framework which places nationalism not above everything else, but within the intricate matrix of issues arising in the latter decades of the Monarchy and continuing into the successor states. Already at the 1967 Austrian History Yearbook conference, the comparative historian Raymond Grew suggested that 'nationalism was less the cause [of the Monarchy's difficulties] than another reflection of the political and social difficulties the empire faced' ${ }^{31}$ Conceptualising a wider framework, while also incorporating the tremendous variety of recent research and viewpoints, presents a stimulating and difficult challenge for any historian of the region.

Dr. Jonathan Kwan

Lecturer in Modern History

University of Nottingham

School of History

University Park

Nottingham

NG7 2RD

jonathan.kwan@nottingham.ac.uk

01158468090

\footnotetext{
${ }^{1}$ Paul Schroeder, 'The Status of Habsburg Studies in the United States', Austrian History Yearbook 3 (1967) 3, p. 267.

${ }^{2}$ Not all historians at the 1967 conference agreed with this paradigm. Hans Kohn, a son of pre-WWI Prague, in his contribution stated simply that:

It seems to me that their [other historians] consensus is that the nationality problems and the difficulty of their solutions made the collapse of the monarchy inevitable. I do not share this opinion
} 
He continued in the same vein:

Nowhere were the majority of the various nationalities in principle anti-Habsburg or antimonarchist before 1914 ... With a different foreign policy in Francis Joseph's long reign there could have been more time, at least in the Austrian part of the Dual Monarchy, to pursue a successful domestic policy of patience, of flexibility, of mutual concessions and bargains - a policy in no way alien to the Austrian temperament and more or less acceptable to its various nationalities.

See Hans Kohn, 'Was the Collapse Inevitable?', Austrian History Yearbook 3 (1967) 3, pp. 250 and 263. Similarly Joachim Remak in an essay published in 1969 stated that 'it was not the nationality issue which doomed the empire. An unwise foreign policy, and a war against an overwhelming coalition were quite enough'. Joachim Remak, 'The Healthy Invalid: How Doomed the Habsburg Empire?', Journal of Modern History 41 (1969) 2, p. 143.

${ }^{3}$ Oscar Jaszi, The Dissolution of the Habsburg Monarchy (Chicago 1929), p. 453.

${ }^{4}$ Ibid.

${ }^{5}$ Pieter Judson review of 'Laurence Cole and Daniel Unowsky (eds.), The Limits of Loyalty' in Central European History 42 (2009) 1, p. 152. Judson does not use the exact term 'quiet revolution', which I have coined from his suggestive review.

${ }^{6}$ Alois Brusatti (ed.), Die Habsburgermonarchie 1848-1918. Vol. 1: Die Wirtschaftliche Entwicklung (Vienna 1973). Adam Wandruszka describes the genesis of the series in the introduction to the volume. For a good summation of the economic revisionist view see David Good, The Economic Rise of the Habsburg Empire 1750-1914 (Berkeley 1984). For a recent short and incisive assessment of the

Habsburgermonarchie project see R.J.W. Evans, 'The Habsburg Monarchy, 1848-1918, and the

Habsburgermonarchie Project', English Historical Review 122 (2007), pp. 1016-22.

${ }^{7}$ Gary Cohen, 'Nationalist Politics and the Dynamics of State and Civil Society in the Habsburg Monarchy, 1867-1914', Central European History 40 (2007) 2, p. 274.

${ }^{8}$ Ibid, p. 276.

${ }^{9}$ Ibid, p. 277.

${ }^{10}$ Ibid, p. 266.

${ }^{11}$ Margaret Anderson, Practising Democracy. Elections and Political Culture in Imperial Germany (Princeton 2000). For the Habsburg Monarchy and its Rechtsstaat see James Shedel, 'Fin-de-Siècle or Jahrhundertwende. The Question of an Austrian Sonderweg' in Steven Beller (ed.), Rethinking Vienna 1900 (New York 2001), pp. 80-104 and Adam Wandruszka, 'Ein vorbildlicher Rechtsstaat' in Adam Wandruszka and Peter Urbanitsch (eds.), Die Habsburgermonarchie 1848-1918. Vol. 2: Verwaltung und Rechtswesen (Vienna 1975), pp. ix-xviii.

${ }^{12}$ Laurence Cole, 'Introduction: Re-examining National Identity in Nineteenth-Century Central Europe and Italy' in Laurence Cole (ed.), Different Paths to the Nation. Regional and National Identities in Central Europe and Italy, 1830-70 (Basingstoke 2007), p. 1.

${ }^{13}$ I take the phrase 'remarkable pluralism' from the recent historiographical survey of Wilhelmine Germany. Matthew Jeffries, Contesting the German Empire, 1871-1918 (Oxford 2008), p. 3.

${ }^{14}$ For example see Josef Redlich, Das österreichische Staats- und Reichsproblem. Vol. 1 (Leipzig 1920), pp. 673-799. Brita Skottersberg and Fritz Fellner follow Redlich's harsh judgement. See Brita Skottsberg, Der österreichisch ist Parlamentarismus (Göteburg 1940), pp. 31 and Fritz Fellner, 'Das "Februarpatent" von 1861', Mittheilungen des Instituts für österreichische Geschichtsforschung 63 (1955), p. 562-3. In general the English language historiography has followed the same line see A.J.P. Taylor, The Habsburg Monarchy 1809-1918: A History of the Austrian Empire and Austria-Hungary (London 1972), p. 123. The Chapter title contains the phrase 'constitutional absolutism' and in the text Taylor writes of a 'sham parliament'.

${ }^{15}$ Scebek was elected in Prague and Porak in Trautenau.

${ }^{16}$ Lothar Hoebelt, 'The Great Landowner's Curia and the Reichsrat Elections during the Formative Years of Austrian Constitutionalism 1867-1873', Parliaments, Estates and Representation 5 (1985) 2, pp. 175-83.

${ }^{17}$ Place names are notoriously contentious in Central and Eastern Europe. I have used any common English names where possible (eg. Prague, Vienna). Otherwise at the first reference I have given different variants and then for convenience sake the place name in the language of the majority within the specific town or region at the specific time. 
${ }^{18}$ There are some examples but the field still remains rather neglected. See Oskar Krejčí, History of Elections in Bohemia and Moravia (Boulder 1995) is very general and Adalbert Toth, Parteien und Reichstagswahlen in Ungarn, 1848-1892 (Munich 1973) very statistical in orientation with the analysis mostly focussed on political parties and sociological background rather than elections. For Imperial Germany there has been considerably more research in these fields. See the summary in Jeffries, Contesting the German Empire, pp. 90-125.

${ }^{19}$ As Glassheim notes these words are very reminiscent of the aristocratic sentiments in the great novel of Sicilian nobility, The Leopard by Giuseppe Tomasi di Lampedusa.

${ }^{20}$ Jeremy King, Budweisers into Czechs and Germans: A Local History of Bohemian Politics, 1848-1948 (Princeton 2002).

${ }^{21}$ Rita Krueger, Czech, German, and Noble. Status and National Identity in Habsburg Bohemia (New York 2008) and Ralph Melville, Adel und Revolution in Böhmen: Strukturwandel von Herrschaft und Gesellschaft in Österreich um die Mitte des 19. Jahrhunderts (Mainz 1998).

${ }^{22}$ Lothar Hoebelt, Kornblume und Kaiseradler: Die deutschfreiheitlichen Parteien Altösterreichs 18821918 (Munich and Vienna 1993).

${ }^{23}$ For Hungary see the classic work of Robert Seton-Watson, Corruption and Reform in Hungary: A Study of Electoral Practice (London 1911) and the more recent comments in Andras Gero, The Hungarian Parliament (1867-1918): A Mirage of Power (Boulder 1997).

${ }^{24}$ Robin Okey, Eastern Europe, 1740-1985: Feudalism to Communism (London 1986) and Robin Okey, The Habsburg Monarchy, c1765-1918: From Enlightenment to Eclipse (London 2000).

${ }^{25}$ See also Nancy Wingfield, Minority Politics in a Multinational State; The German Social Democrats in Czechoslovakia, 1918-1938 (Boulder 1989).

${ }^{26}$ Rottenbacher, Das Februarpatent in der Praxis, p. 313.

${ }^{27}$ Another recent book uses the term 'national indifference' for the Upper Silesian region and argues for the salience of religion in politics and public life. James Bjork, Neither German nor Pole. Catholicism and National Indifference in a Central European Borderland (Ann Arbor 2008).

${ }^{28}$ The Moravian Compromise recognised nationality as an administrative category and determined rights accordingly. Lex Perek stated that children could only enter an elementary school if they were proficient in the language used at the school.

${ }^{29}$ See for example Keely Stauter-Halsted, A Nation in the Village. The Genesis of Peasant National Identity in Austrian Poland (Ithaca 2001).

${ }^{30}$ Karl Heinz Rossbacher, Literatur und Bürgertum. Fünf Wiener jüdische Familien von der liberalen Ära zum Fin-de-Siècle (Vienna 2003).

${ }^{31}$ Raymond Grew, 'Comments', Austrian History Yearbook 3 (1967) 2, p. 489. 